\title{
Non Hormonal Factors Influencing Reproductive Efficiency in Black Bengal Goat
}

\author{
A. Patra ${ }^{1}$, C.K. Biswas ${ }^{2 *}$, N. Ghosh ${ }^{3}$ and P.S. Chakrabortty ${ }^{2}$ \\ ${ }^{1}$ SAHC, Chapra, Nadia, West Bengal, India \\ ${ }^{2}$ Department of Animal Science, BCKV, Mohanpur, Nadia, West Bengal, India \\ ${ }^{3}$ Faculty of Veterinary and Animal Science, West Bengal University of Animal and Fishery \\ Sciences, Mohanpur, Nadia, West Bengal, India \\ *Corresponding author
}

\section{A B S T R A C T}

\section{Keywords}

Black Bengal goat, Reproductive efficiency, Buck effect, Nutritional supplementation

Article Info

Accepted:

07 July 2019

Available Online:

10 August 2019
The study was conducted in female Black Bengal goat to investigate the effect of non hormonal factors on reproductive efficiency. Female kids of three months of age were placed in three groups with five numbers in each group; $1^{\text {st }}$ TG with supplementary nutrition and a buck, $2^{\text {nd }}$ TG with supplementary nutrition and $3^{\text {rd }}$ TG as control. Due to permanent exposure of buck and good plane of nutrition, the animals under TG 1 attained puberty significantly $(\mathrm{P}<0.01)$ earlier than other two groups. Average body weight of animals of TG1 $(10.0 \mathrm{~kg})$ was also recorded to be lowest. Most failure of conception was noted in TG 1 as reflected by its significantly higher $(\mathrm{P}<0.05)$ number of services $(3.6)$ than other two groups $(2.2$ and 2.0 respectively). Nonsignificant $(\mathrm{P}>0.05)$ variation in gestational length indicated non-hormonal factors had no effect on length of gestation. Highly significant $(\mathrm{P}<0.01)$ variation in respect to age of $1^{\text {st }}$ kidding was observed, the animals under TG 1 took least time, but body weight of animals of TG 3 was least. Post-partum estrus was also recorded to be earliest (3 to 6 weeks) in first group of animals than the other two.

\section{Introduction}

Goat husbandry plays an important role in Indian rural economy. There is an increased demand for goat meat consumption over the years. As per the recommendations by Indian Council of Medical Research (ICMR), the daily allowance of meat is $34 \mathrm{~g}$, but the per capita meat consumption is as low as $14 \mathrm{~g}$ per day. Though more people prefer chevon over beef the production of chevon is only 10 percent of the total meat. The level of goat meat production to meet domestic and global demand can be possible by producing faster growing goats or by improving their reproductive efficiency. Among thirty four descriptive breeds of goats in India (www.nbagr.res.in) Black Bengal goat is famous for the delicious meat and superior quality skin and higher prolificacy. Its 
reproductive efficiency can be improved by using hormones which may not be safe for human consumption. On the other hand use of balanced nutrition and/or introduction of buck in females' flock may be other non-hazardous ways to induce better reproductive functioning leading to higher kidding size. Keeping this in view the present investigation was undertaken to improve the reproductive efficiency of female Black Bengal goats by different nonhormonal factors to have better quality goat products.

\section{Materials and Methods}

The present study was undertaken in the Livestock Instructional Farm, Bidhan Chandra Krishi Viswavidyalaya, Mohanpur, Nadia, West Bengal, India during the period from April 2010 to March 2012. The experiment was conducted in Completely Randomized Design (CRD) with three treatments, viz. i) Nutritional effect and buck effect, ii) Nutritional effect and iii) Control (without nutritional and buck effect). Fifteen female Black Bengal kids, true to the type of three months of age obtained from the pure stock of NFBSFARA project of ICAR were allotted randomly with five kids in each group. The first group of animals was allowed to graze 67 hours per day spread over morning and afternoon session and they only were kept with a buck of one year of age while the other two groups of animals were stall fed with the similar type of cut grass ad lib.

The animals of $1^{\text {st }}$ and $2^{\text {nd }}$ group were also provided with concentrate feed supplement (21 percent CP) @ 10g per kg body weight per day in two divided doses. The animals under control group were neither provided the concentrate feed supplement nor kept with the buck. The $1^{\text {st }}$ group of animals was distantly placed to avoid any buck effect on other two groups of experimental animals. All the animals were placed in comfortable sheds and were under standard management practices including health care protocol. The weight of the animals was taken with the help of dial type spring balance (Salter, $20 \mathrm{~kg}$ capacity with $200 \mathrm{~g}$ graduation) and expressed in $\mathrm{kg}$. Different reproductive parameters viz. age of $1^{\text {st }}$ estrus, number of services per conception, length of gestation, age of $1^{\text {st }}$ kidding, kidding size and post-partum heat were recorded as per standard protocol. The data were analysed statistically by the analysis of variance (ANOVA) method, described by Cochroan and Cox (1967) and Panse and Sukhatme (1967). Error mean square by Fisher and Snedecor's F-test method was followed to test significance of different sources of variation. The standard error $\left(\mathrm{S}_{\mathrm{e}}\right)$ and test of significance have been provided in the table of results to compare the mean values.

\section{Results and Discussion}

\section{Age and weight of animals to attain puberty}

In the present study, it was evident that the animals under first treatment group showed symptoms of puberty at the age between eight to nine months (Table 1). In contrast, the animals under second and third treatment group attained puberty later than the first group which was about eleven to twelve months and thirteen to fourteen months, respectively. The average age of the animals under three treatment groups were 259, 346.0 and 422.2 days, respectively, the differences being highly significant ( $1 \%$ level).

The average body weights of the animals at puberty were $10 \mathrm{~kg}, 11.1 \mathrm{~kg}$ and $11.04 \mathrm{~kg}$ for first, second and third treatment group respectively (Fig. 1). The average weight of the animals under the first treatment group was lower $(\mathrm{P}<0.05)$ than that of the second and third groups; whereas there was no significant difference between that of the second and third group was observed. 
The result of the present experiment suggested the same, as explained by David et al., (2001), and the findings were similar with that of Hossain et al., (2004), where it was noted that young female attained puberty at an age and weight of $209 \pm 32.25$ days and $8.08 \pm 1.28 \mathrm{~kg}$ respectively. It was reported by Faruque et al., (2010) that the young Black Bengal female goats attained puberty at an age and weight of $186.02 \pm 10.52$ days and $9.4 \pm 0.52 \mathrm{~kg}$, respectively. In case of intensive rearing system it took 139 days to show first heat compared to 198 days in semi-intensive rearing system.

\section{Age and weight of animals at first kidding}

It was evident from the present study that the first kidding of the animals under the first treatment group was earlier than the second and third group of animals (Table 2). Average days required for first kidding in first treatment group was noted as 489.4 days; whereas average days required for animals under second treatment group was 636.4 days. The variation was measured to be highly significant $(\mathrm{P}<0.01)$. It was interesting to note that all the animals under the third treatment group could not attain successful pregnancy during the experimental period. Only three animals out of five had parturition at the average age of 670.6 days. Regarding the average body weight of the animals before parturition after first pregnancy, under two treatment groups it was recorded that the animals of both the groups attained $14.2 \mathrm{~kg}$ body weight, while the animals of the third group attained $13.0 \mathrm{~kg}$ (Table 3). Although the first and second treatment group showed same body weight before parturition but the second group had higher age at that time, which indicated good body weight was essential for better reproductive performances. The weight of animal is related to the age of puberty. Lower body weight causes delayed puberty. In the present experiment, it was evident that the third group attained puberty with lower body weight at later age than that of the first and second group.

The findings of the present study corroborated with the findings of Hossain et al., (2004). It was reported by Kumar et al., (2011) that Black Bengal goats had significantly lower age at first conception and age at first kidding. The mean age and weight at first kidding were $401.5 \pm 32.08$ days and $15.41 \pm 1.35 \mathrm{~kg}$, respectively, in Black Bengal goats. According to the present result the age of first kidding was higher than the findings by Hossain et al., (2004). This might be due to operational stress of the animals as stated earlier.

\section{Number of services required to attain successful pregnancy}

After attaining puberty the animals were not pregnant with a single service. Animal of all the groups required more than one services to attain successful pregnancy. Average number of required services varied among the animals of three treatment groups. The first, second and third group of animals required 3.6, 2.2 and 2.0 services, respectively, to attain successful pregnancy (Fig. 2), the variation was noted to be significant $(\mathrm{P}<0.05)$. On the contrary, only three animals under third treatment group became pregnant with less number of services. Two animals under third treatment group could not become pregnant even after few services.

The number of services for successful pregnancy was less in number among the animals under the second and third treatment group than the first group. They also needed on an average two services to become pregnant successfully. As per the findings of Faruque et al., (2010) the number of services required for each successful conception was $1.16 \pm 0.019$. The findings of Garci et al., 
(1996), Amin et al., (2001) and Faruque et al., (2002) were also similar. The findings of the present study were different from them because of the fact that, the animals experienced operational stress at an early age which might be the cause of more number of services per pregnancy.

\section{Length of gestation period}

The length of gestation period was 147.8, 147.6 and 147.0 days of the animals under the first, second and third treatment groups respectively (Fig. 3). There was no variation (P>0.05) among the animals of different treatment groups, regarding the gestation period of the animals.

Only three animals out of five of the third group experienced pregnancy.

Thus it can be said that nutrition and buck effect have no influence on the gestational length of goat.

Table.1 Age (days) of first service of animals under different treatments

\begin{tabular}{|c|c|c|c|c|c|c|c|}
\hline \multicolumn{2}{|c|}{$\begin{array}{c}\text { Animal number in respective } \\
\text { treatment group }\end{array}$} & $\mathbf{1}$ & $\mathbf{2}$ & $\mathbf{3}$ & $\mathbf{4}$ & $\mathbf{5}$ & Mean \\
\hline Treatment Group (TG) & TG-1 & 259 & 252 & 273 & 252 & 259 & $\mathbf{2 5 9 . 0}$ \\
\cline { 2 - 9 } & TG-2 & 345 & 343 & 355 & 340 & 347 & $\mathbf{3 4 6 . 0}$ \\
\cline { 2 - 9 } & TG-3 & 421 & 411 & 428 & 436 & 415 & $\mathbf{4 2 2 . 2}$ \\
\hline
\end{tabular}

$\mathrm{S}_{\mathrm{e}}=2.74 ;$ significant at $1 \%$ level

Table.2 Age (days) of first kidding of animals under different treatments

\begin{tabular}{|c|c|c|c|c|c|c|c|}
\hline \multicolumn{2}{|c|}{$\begin{array}{c}\text { Animal number in respective } \\
\text { treatment group }\end{array}$} & $\mathbf{1}$ & $\mathbf{2}$ & $\mathbf{3}$ & $\mathbf{4}$ & $\mathbf{5}$ & Mean \\
\hline Treatment Group (TG) & TG-1 & 491 & 483 & 477 & 491 & 505 & $\mathbf{4 8 9 . 4}$ \\
\cline { 2 - 9 } & TG-2 & 651 & 622 & 635 & 641 & 633 & $\mathbf{6 3 6 . 4}$ \\
\cline { 2 - 9 } & TG-3 & $\begin{array}{c}\text { No } \\
\text { Kidding }\end{array}$ & 672 & 661 & $\begin{array}{c}\text { No } \\
\text { Kidding }\end{array}$ & 679 & $\mathbf{6 7 0 . 6}$ \\
\hline
\end{tabular}

$\mathrm{S}_{\mathrm{e}}=11.23 ;$ significant at $1 \%$ level

Table.3 Weight of the animals $(\mathrm{kg})$ at $1^{\text {st }}$ kidding under different treatments

\begin{tabular}{|c|c|c|c|c|c|c|c|}
\hline \multicolumn{2}{|c|}{$\begin{array}{c}\text { Animal number in respective } \\
\text { treatment group }\end{array}$} & $\mathbf{1}$ & $\mathbf{2}$ & $\mathbf{3}$ & $\mathbf{4}$ & $\mathbf{5}$ & Mean \\
\hline Treatment Group (TG) & TG-1 & 13.5 & 14.5 & 13 & 16.5 & 13.5 & $\mathbf{1 4 . 2}$ \\
\cline { 2 - 9 } & TG-2 & 14 & 14.5 & 13 & 15 & 14.5 & $\mathbf{1 4 . 2}$ \\
\cline { 2 - 8 } & TG-3 & $\begin{array}{c}\text { No } \\
\text { Kidding }\end{array}$ & 13 & 13.2 & $\begin{array}{c}\text { No } \\
\text { Kidding }\end{array}$ & 12.8 & $\mathbf{1 3 . 0}$ \\
\hline
\end{tabular}

$\mathrm{S}_{\mathrm{e}}=0.27 ;$ significant at $5 \%$ level 
Table.4 Time required (week) to come to post-partum estrous after first parturition

\begin{tabular}{|c|c|c|c|c|c|c|}
\hline $\begin{array}{c}\text { Animal number in respective } \\
\text { treatment group }\end{array}$ & $\mathbf{1}$ & $\mathbf{2}$ & $\mathbf{3}$ & $\mathbf{4}$ & $\mathbf{5}$ \\
\hline $\begin{array}{c}\text { Treatment } \\
\text { Group (TG) }\end{array}$ & TG-1 & 4 & 3 & 6 & 5 & 5 \\
\cline { 2 - 7 } & TG-2 & 10 & 13 & $\begin{array}{c}\text { Showed no } \\
\text { estrous }\end{array}$ & $\begin{array}{c}\text { Showed no } \\
\text { estrous }\end{array}$ & $\begin{array}{c}\text { Showed no } \\
\text { estrous }\end{array}$ \\
\cline { 2 - 7 } & TG-3 & $\begin{array}{c}\text { No } \\
\text { Pregnancy }\end{array}$ & $\begin{array}{c}\text { Showed no } \\
\text { estrous }\end{array}$ & $\begin{array}{c}\text { Showed no } \\
\text { estrous }\end{array}$ & $\begin{array}{c}\text { No } \\
\text { Pregnancy }\end{array}$ & $\begin{array}{c}\text { Showed no } \\
\text { estrous }\end{array}$ \\
\hline
\end{tabular}

Fig.1 Weight $(\mathrm{kg})$ of the animals at puberty under different treatments

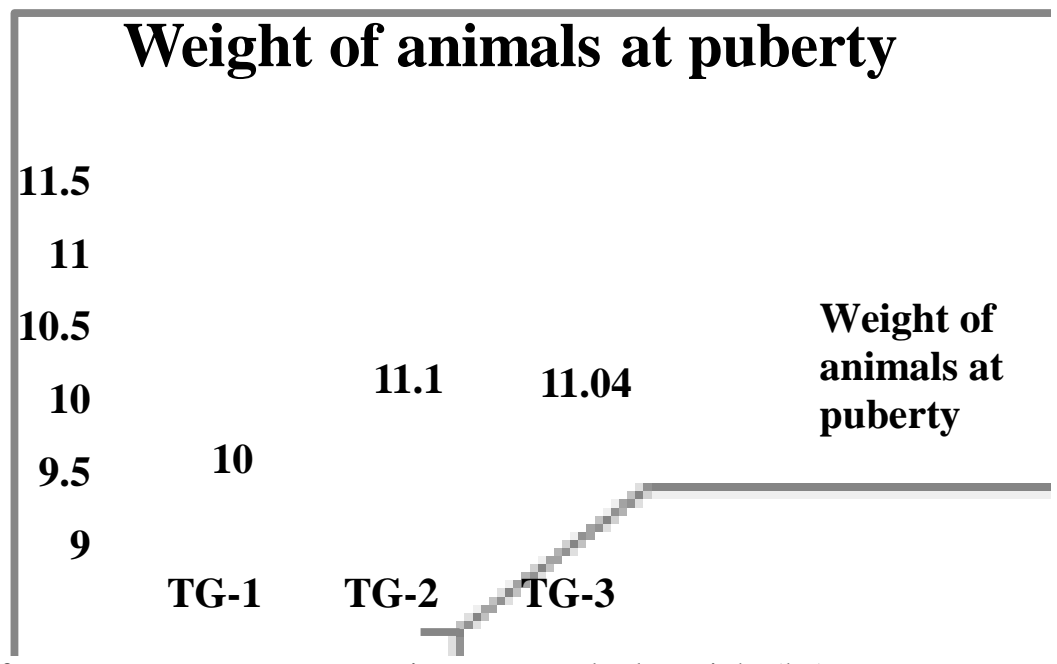

[X-axis represents different treatment groups; Y-axis represents body weight $(\mathrm{kg})]$

Fig.2 Number of services required to attain successful pregnancy under different treatments

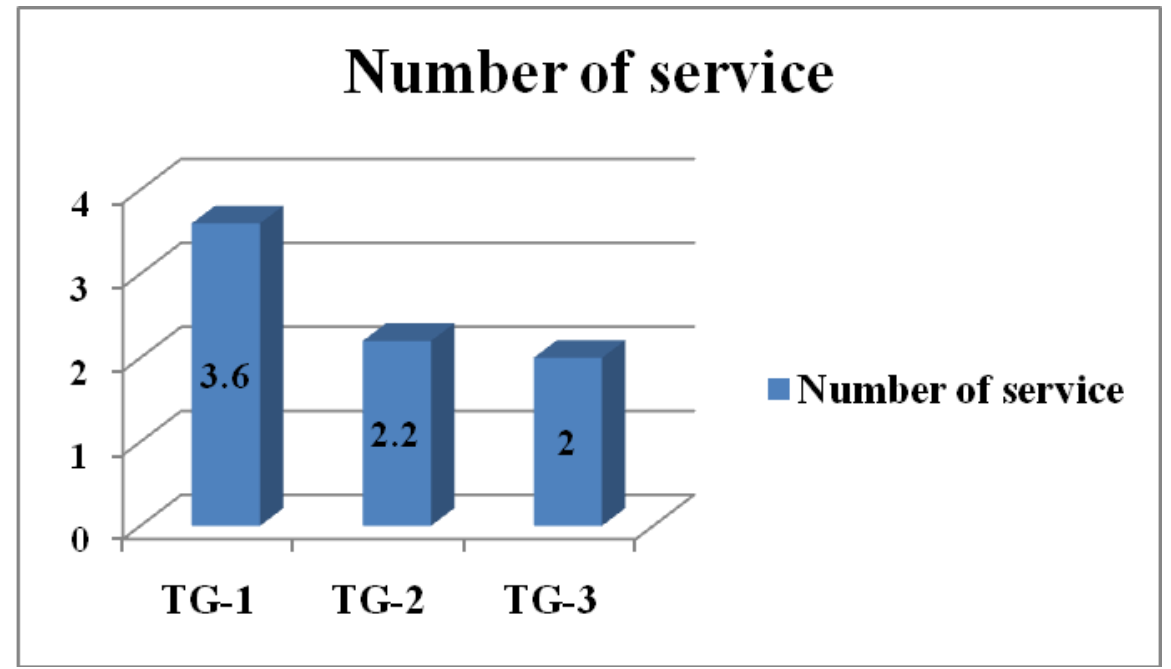

[X-axis represents different treatment groups and Y-axis represents number of services 
Fig.3 Length of gestation period of animals under different treatments

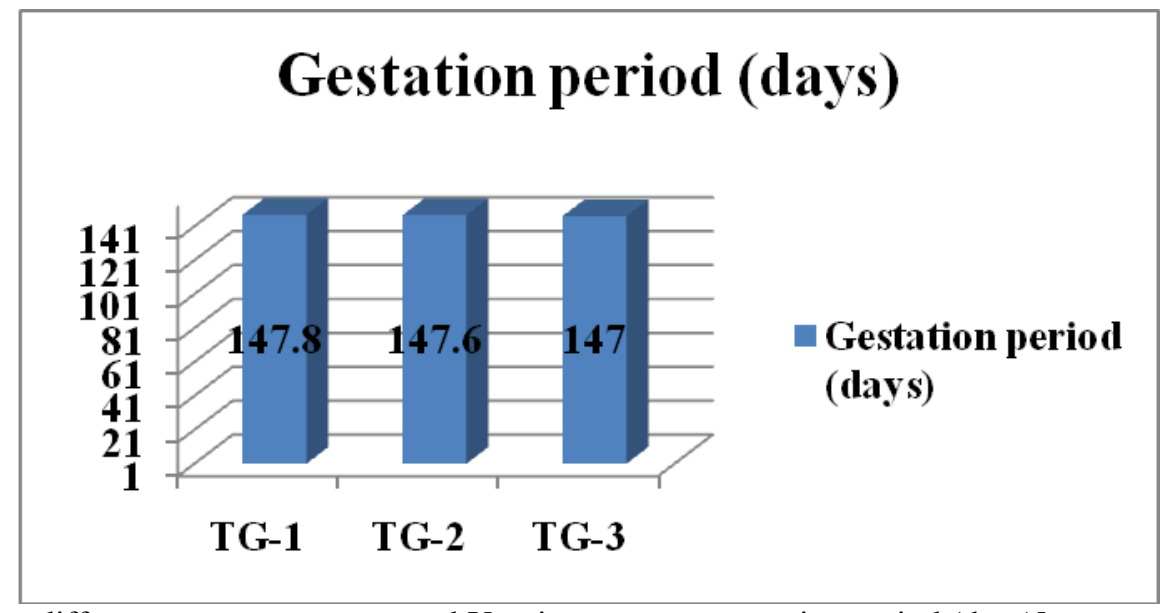

[X-axis represents different treatment groups and $\mathrm{Y}$-axis represents gestation period (days)]

Average gestation length observed was $143.33+0.68$ days by Faruque et al., (2010). In West African Dwarf goats gestation length was reported as $141.3+4.7$ days by Otchere and Nimo (1975) and 146.2+2.7 days by Montsma et al., (1981). But Gupta et al., (1964) reported 145 days gestation length for Black Bengal goat. The observation of the present study regarding gestation period of Black Bengal goats varied between 145to 149 days which corroborated with the previous studies.

Time required for onset of post-partum heat after first kidding

It was noticed that the time required for coming to post-partum estrous after first kidding varied among the three treatment groups (Table 4). It was noted that the animals under the first treatment group showed estrous symptoms soon after parturition within three to six weeks. Among the animals under second treatment group only two animals came to estrous after parturition. The time taken for coming to estrous was much higher (10 to 13 weeks) than those of first group and the rest three animals showed no estrous symptoms after parturition within the period of experimentation. On the other hand, among the animals under third treatment group, three animals did not show estrous after first pregnancy during the time of experimentation, while two animals did not attain pregnancy within the particular period. It was reported by Hossain et al., (2004) that the post-partum heat was 48 days for first parity.

Goats are generally considered as seasonally polyestrous animals in the temperate regions. But in warm climates, where there is little seasonal variation, i.e. in the warmer equatorial regions, goats may not exhibit this seasonal heat pattern. So, it is not uncommon to see heat cycles occurring throughout the year in those regions. Black Bengal goats are one breed, which has no seasonal variation regarding estrous cycle. The induction of puberty is influenced by different external factors like, nutrition, season of year, proximity of male, climate and disease. Nutrition is one of the important factors regarding attaining puberty, because well fed animals reach better body weight. 'Male effect' is mediated by pheromonal and sensory cues influencing hypothalamic $\mathrm{GnRH}$ secretion. Anthropomorphic extrapolation has assumed that animals living in tropics reach 
puberty at an earlier age than those in temperate climate. Any kind of disease interferes with the growth rate directly or indirectly, which delays the onset of puberty (David et al., 2001).

As per the design of the experiment, all the animals experienced surgical stress on $11^{\text {th }}$ day of service through exploratory laparotomy. The animals under first and second treatment group could recover from the stress of the operation because of getting good plane of nutrition. But on the contrary, the animals under the third treatment group could not recover properly from the stress of operation due to lack of nutrition. As a result, some of them could not become pregnant successfully within the period of experimentation.

Animals under second and third treatment group had no 'buck effect'. So, there was long time anestrous and animals were not serviceable at the anestrous period eventually. These animals were in estrous only for two to three times before attaining successful pregnancy. So, they experienced less number of services to attain the pregnancy. The number of estrous of the animals under first treatment group was more than that of the rest of thetwo groups. The estrous cycle was regular in the animals of the first group. Probably due to operational stress, they could not become pregnant with one or two services, but became pregnant earlier than the second group due to availability of buck as per their need. It was noticed that, the animals with more than one parity could successfully complete their pregnancy period with successful kidding (NFBSFARA-Annual Report, 2009-10) even after exploratory laparotomy. But in the present study all the animals needed more than one services to attain successful pregnancy as all animals were in first parity and experienced operational stress. Animals of the first and second groups had good plane of nutrition. So, even after operational stress all of the animals could attain successful pregnancy after a number of services. But the third group had no 'buck effect' as well as good nutrition. That is why; all the animals could not overcome the operational stress after laparotomy.

The reason behind this variation in onset of post-partum estrus may be explained by the presence of bucks among the animals under first treatment group. The animals under first and second treatment group received same type of feeding. So, nutritionally they were not in much different condition, they were different only in respect of buck effect. Presence of buck among the first group of animals helped them to come to estrous earlier than the second and third group of animals. Animals under third group had no good nutritional support and effect of buck. So, the animals after first kidding did not come to post-partum heat within the period of experimentation.

\section{Acknowledgement}

The necessary support extended by the Vice Chancellor, Bidhan Chandra Krishi Viswavidyalaya, West Bengal, the Dean, Faculty of Agriculture, Bidhan Chandra Krishi Viswavidyalaya, West Bengal and Indian Council of Agricultural Research, New Delhi for providing laboratory support through the NFBSFARA Project on Black Bengal goat are duly acknowledged.

\section{References}

Amin, M.R., Husain, S.S. and Islam, A.B.M.M. 2001. Reproductive peculiarities and litter weight in different genetic groups of Black Bengal does. Asian-Australasian Journal of Animal Science. 14(3): 297- 
301.

Annual Report, NFBSFARA, 2009-10. Project title: Endocrine profiles and characterization of candidate genes influencing prolificacy in black Bengal goat.

Cochran, W.G. and Cox, G.M. 1967. Experimental Designs, Modern Asia edition, Charles, E. Tuttb Co., Tokyo, Fifth printing pg 95.

David, E., Noakes Timothy, Parkinson, J. and Gary, C.W. Edited 2001. Arthur's Veterinary Reproduction and Obstetrics. WB Saunders Company Harcourt (India) Pvt. Ltd. pg: 3-56.

Faruque, S., Husain, S.S., Rahman, M.M., Roy, B.K., Islam, M.N. and Islam, M.S. 2002.A study on the reproductive performance of does in different genetic groups under village condition.Online Journal of Biological Sciences. 2(5): 325-328.

Faruque, S., Chowdhury, S.A., Siddiqueeand, N. U., Afroz, M. A. 2010. Performance and genetic parameters of economically important traits of Black Bengal goat. $J$. Bangladesh Agril. Univ. 8(1): 67-78.

Garci, B.O., Garcia, B.E., Bravo, J. and Bradford, E. 1996. Analysis of a crossbreeding trial with Criollo and imported goats. 6. Other reproductive traits. Revista-de-la-Facultad-deAgronomia, Universidad-del-Zulia. 13 (5): 597-609.
Gupta, S., Som, T.L. and Bhattacharyya, S. 1964. Studies on gestation length in Black Bengal goats. Indian Veterinary Journal. 41: 668-672.

Hossain, S.M.J., Sultana, N., Alam, M.R. and Hasnath, M.R. 2004. Reproductive and productive performance of Black Bengal Goat under semi-intensive management. Journal of Biological Sciences. 4(4): 537-541.

http://www.nbagr.res.in

Kumar, A., Singh, L.B., Kumar, D. and Ahmad, M. (2011) Factors affecting reproductive traits in Black Bengal and Beetal $\times$ Black Bengal crosses. Indian Journal of Small Ruminants, 17 (2): 225-226.

Montsama, G., Groen, A. and Hofs, P. 1981. Efficiency of meat production in dwarf goats. In intensive animal production in develop countries. Thames Ditton, U.K., British Society for Animal Production, 429-434. Occasional publication, British Society of Animal Production, 4.

Otchere, E.O. and Nimo, M.C. 1975. Observations on the reproductive behaviour in the West African dwarf goat. Ghana J Agricul. Sci. 8: 187-190 (ABA 47, 2364).

Panse, V.G. and Sukhatme, P.V. 1967. Statistical methods for agricultural workers. ICAR, New Delhi India. Pg381.

\section{How to cite this article:}

Patra, A., C.K. Biswas, N. Ghosh and Chakrabortty, P.S. 2019. Non Hormonal Factors Influencing Reproductive Efficiency in Black Bengal Goat. Int.J.Curr.Microbiol.App.Sci. 8(08): 722-729. doi: https://doi.org/10.20546/ijcmas.2019.808.082 